\title{
The oceanic cycles of the transition metals and their isotopes
}

\author{
Derek Vance $^{1}$ (D) Corey Archer $^{1} \cdot$ Susan H. Little $^{2} \cdot$ Michael Köbberich ${ }^{1}$. \\ Gregory F. de Souza ${ }^{1}$
}

Received: 28 March 2017/Revised: 16 April 2017/Accepted: 16 April 2017/Published online: 3 May 2017

(C) The Author(s) 2017. This article is an open access publication

\begin{abstract}
The stable isotope systems of the transition metals potentially provide constraints on the current and past operation of the biological pump, and on the state of ocean redox in Earth history. Here we focus on two exemplar metals, nickel $(\mathrm{Ni})$ and zinc $(\mathrm{Zn})$. The oceanic dissolved pool of both elements is isotopically heavier than the known inputs, implying an output with light isotope compositions. The modern oceanic cycle of both these elements is dominated by biological uptake into photosynthesised organic matter and output to sediment. It is increasingly clear, however, that such uptake is associated with only very minor isotope fractionation. We suggest that the isotopic balance is instead closed by the sequestration of light isotopes to sulphide in anoxic and organic-rich sediments, so that it is ocean chemistry that controls these isotope systems, and suggesting a different but equally interesting array of questions in Earth history that can be addressed with these systems.
\end{abstract}

Keywords Ocean biogeochemistry $\cdot$ Metal micronutrients $\cdot$ Stable isotopes

The original version of this article was revised due to a retrospective Open Access order.

11th International Symposium on Geochemistry of the Earth's Surface.

Derek Vance

derek.vance@erdw.ethz.ch

1 Department of Earth Sciences, Institute of Geochemistry and Petrology, ETH Zürich, Clausiusstrasse 25, 8092 Zürich, Switzerland

2 Department of Earth Science and Engineering, Imperial College London, South Kensington Campus, Exhibition Road, London SW7 2AZ, UK

\section{Introduction}

Many transition metals are important players in ocean biogeochemistry (e.g. Morel et al. 2014). Oceanic phytoplankton are responsible for about half the photosynthetic carbon fixation on Earth, and the biochemical mechanisms they use to fix this carbon require essential trace metal micronutrients $(\mathrm{Fe}, \mathrm{Zn}, \mathrm{Cd}, \mathrm{Ni}$, among others) in addition to the major nutrients $(\mathrm{C}, \mathrm{P}, \mathrm{N}, \mathrm{Si})$. As a result, these trace metal micronutrients display "nutrient-like" depth profiles in the modern ocean (Bruland et al. 2014): their dissolved concentrations are small, sometimes vanishingly small, in the sunlit upper ocean where phytoplankton uptake depletes them. In the deep ocean, where respiration regenerates them into the dissolved phase, their concentrations are often 2-3 orders of magnitude higher. Thus, when the stable isotope systems of these systems were first developed, and given that cellular uptake often induces substantial isotope fractionations, there was significant hope that they could be used as tracers of these processes on the recent Earth. Moreover, different groups of microbial organisms have different requirements for different metals. For example, methanogens have an obligate requirement for large amounts of $\mathrm{Ni}$, prokaryotic bacteria need much more $\mathrm{Fe}$ and Mo than do eukaryotes, the requirement for $\mathrm{Cu}$ and $\mathrm{Zn}$ is more pronounced in eukaryotic algae. Thus, there also seemed to be potential for tracking the evolution of the biosphere as a whole, particularly in the approximately 4 Gyr of Earth history before multi-cellularity and macroscopic fossils appeared.

However, a complicating factor in attempts to harness transition metal isotopes for the study of the oceanic biosphere alone lies in their sensitivity to redox, and in particular their reactivity towards dissolved sulphide. In this contribution we focus on two of these metals- $\mathrm{Zn}$ and 
$\mathrm{Ni}$ - and highlight recent work on the water column of the modern oceans, on sediments deposited from the past and present ocean, and on experimental and theoretical work. These studies have dampened the expectations that the stable isotope systems of these metals can tell us much in a direct way about their importance to the biosphere. However, the importance of their aqueous chemistry for stable isotope variations presents a very different and equally exciting opportunity: their potential to help us understand major changes in ocean chemistry through time.

\section{Modern water column processes-new data from the GEOTRACES programme}

Our understanding of the behaviour of all trace elements in the oceans is undergoing a step change due to a major current international initiative, the GEOTRACES programme. Building on decades of careful and pioneering work, the chemical oceanography community has been able to overcome the problem of environmental contamination that was once ubiquitously detrimental to the study of the scarce transition metals in the ocean. Through a network of oceanographic cruises equipped with state-ofthe-art sample collection equipment, there is now a growing database for the stable isotope composition of metals such as $\mathrm{Zn}$ and $\mathrm{Ni}$ in the dissolved pool of the oceans, providing a basis for building our understanding of the processes that control them in the present and past ocean. For $\mathrm{Zn}$ and $\mathrm{Ni}$, two key features have emerged from these studies, summarized in Fig. 1. The first is that, as with many of the new isotope systems that have been studied thus far (cf. $\mathrm{Cu}, \mathrm{Mo}$ ), the isotopic composition of the dissolved pool is substantially heavier than our best estimates of the input fluxes to the ocean. This requires either that our knowledge of the inputs is imperfect, or that there are output fluxes that are preferentially removing the light isotopes.

The second feature that has emerged is that biological uptake does not appear to lead to large variations in the isotopic composition of the residual dissolved pool. A key example is for $\mathrm{Zn}$. The modern cycle of many nutrients is dominated by the processing of water through the Southern Ocean by upwelling and the formation of sub-surface water masses that fill large parts of the rest of the ocean. For $\mathrm{Zn}$ (e.g. Vance et al. 2017) this dominance is especially important because the diatoms that strip this water of silicon take up 10 times more $\mathrm{Zn}$ relative to phosphorous than other oceanic phytoplankton. As a result, $\mathrm{Zn}$ concentrations drop by a factor of 40 as water is moved away from the upwelling zone in the surface flow. Despite this stripping, the residual water stripped of $\mathrm{Zn}$ has a $\mathrm{Zn}$ isotope composition that is analytically indistinguishable from the upwelled water. A $\mathrm{Zn}$ isotope fractionation of as little as 0.2 per mil during uptake would lead to very significant differences between pristine upwelled water and the residual stripped water, differences that are not observed. Examination of the data in Fig. 1 suggests that, if anything, the very small inventory of $\mathrm{Zn}$ that remains in the upper $500 \mathrm{~m}$ of the global ocean water columns is shifted towards slightly lighter isotope compositions. The data for $\mathrm{Ni}$ do suggest minor isotope effects due to uptake, leading to marginally heavier $\mathrm{Ni}$ isotope compositions when photic zone Ni concentrations descend to the lowest values. But these effects due to uptake are trivial compared to the degree to which the oceanic dissolved pool as a whole differs from the input.

\section{Constraints on fractionation mechanisms}

In addition to measurements in the real ocean, there is a growing set of constraints on the expected size of fractionation effects due to oceanic processes that derive from both experimental and theoretical approaches. The pioneering culturing study of John et al. (2007) suggested that uptake of $\mathrm{Zn}$ by the single diatom strain that they studied exhibits a variable preference for the light isotope that depends on the bioavailable $\mathrm{Zn}$ concentration in the medium. At the bioavailable $\mathrm{Zn}$ concentrations typical of upwelling zones like the Southern Ocean, the fractionation found in this early culturing experiment is substantial, but is not borne out by the data from the real Southern Ocean outlined above. At the concentrations that are typical of large parts of the surface ocean the fractionation is very small. Subsequent culturing experiments of multiple diatom strains, as well as cyanobacteria and coccolithophorids, over a wider range of environmental variables (e.g. Köbberich and Vance 2017) has led us to the view that fractionation of $\mathrm{Zn}$ isotopes upon uptake is a very minor effect, consistent with the data from the real oceans in Fig. 1. In contrast, other groups have found that sorption of $\mathrm{Zn}$ and $\mathrm{Ni}$ to both cellular and abiotic surfaces leads to substantial fractionations (see review in Moynier et al. 2017), with the heavy isotope preferentially absorbed. In a parallel approach, theoretical calculations have also led to valuable constraints on the magnitude of isotope fractionations. The most important of these for the present contribution is the finding that the transformation of $\mathrm{Ni}$ and $\mathrm{Zn}$ to aqueous sulphide species, which occurs in the Black Sea and probably in pore waters of many anoxic sediments, involves fractionations of $0.6 \% 0-0.8 \%$, with the light isotope preferentially incorporated in the sulphide species (e.g. Fujii et al. 2014). These aqueous sulphide species are very insoluble and are rapidly removed from solution. 

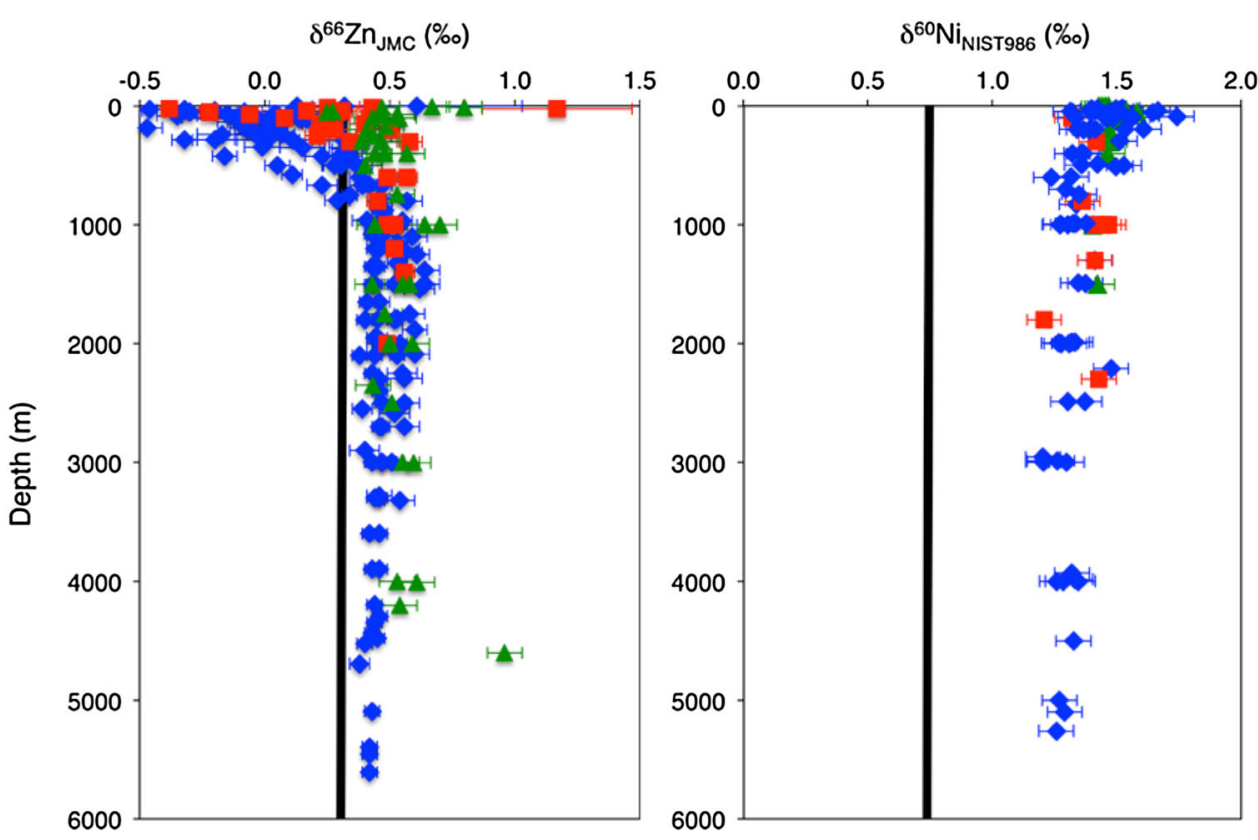

Fig. 1 Zinc and nickel isotope data for the dissolved pool in the open Atlantic (blue), Pacific (red) and Southern (green) Oceans. In both cases, the open ocean is significantly heavier than the known input fluxes (vertical black lines). Note that, for Zn, the lighter isotopic compositions in the upper $500 \mathrm{~m}$ make an insignificant contribution to the overall oceanic average because concentrations are much lower than in the deep ocean. The heavy oceanic isotopic composition relative to the inputs requires a light output flux. $\delta^{66} \mathrm{Zn}_{\mathrm{JMC}}$ is the per mil deviation of the measured ${ }^{66} \mathrm{Zn} /{ }^{64} \mathrm{Zn}$ ratio from the Lyon JMC standard, $\delta^{60} \mathrm{Ni}_{\mathrm{NIST} 986}$ the per mil deviation of the measured ${ }^{60} \mathrm{Ni} /{ }^{58} \mathrm{Ni}$ ratio from NIST SRM986. Most of the Atlantic Zn data are from Conway and John (2014). The remainder of the data are from the ETH Zürich laboratory

\section{Isotope fractionation associated with suphidisation}

Removal of both $\mathrm{Zn}$ and Ni by uptake into phytoplankton cells, and the export of this photosynthesised material to oceanic sediment, is the main pathway by which these metals leave the oceanic dissolved pool. For $\mathrm{Zn}$, given that they account for over half of the primary production that is exported out of the photic zone, and given that their $\mathrm{Zn} / \mathrm{P}$, or $\mathrm{Zn} / \mathrm{C}$, ratios are an order of magnitude greater than other oceanic phytoplankton, diatom uptake and export to sediment must completely dominate. And yet, as argued in the previous two sections, this removal pathway is associated with insignificant isotope effects. So: what is the driver of the heavy isotope compositions of the dissolved oceanic pool, for both $\mathrm{Ni}$ and $\mathrm{Zn}$ ?

Recent work (Vance et al. 2016) on the water column and sediments of the Black Sea suggest a solution to this isotopic conundrum. In the sulphidic deep Black Sea $\mathrm{Zn}$ is very strongly removed, such that deep water concentrations are about $5 \%$ of those just above the chemocline. This is accompanied by $\delta^{66} \mathrm{Zn}$ values that are up to $1.1 \%$ heavier than those in the oxic upper part of the water column. Thus the light isotopes are strongly preferentially removed, via conversion to an aqueous sulphide species and the removal of this species to sediment. $\mathrm{Ni}$ is also removed in the deep Black Sea and, like $\mathrm{Zn}$, displays co-variation between concentrations and isotope compositions in the dissolved phase of the deep sulphidic basin that are consistent with conversion to an aqueous sulphide phase, leaving residual water that is up to $1.2 \%$ heavier than the input. The mass balance for the two elements is different, however. For $\mathrm{Zn}$ the removal is nearly quantitative, so that the authigenic $\mathrm{Zn}$ in the sediment has an isotopic composition that is close to the inputs to the basin. For Ni removal is non-quantitative, so that both sediments and the residual dissolved pool diverge, in opposite directions, from the source. For Ni there is also another process superimposed on this: the addition of metal in particulate form from the basin margins, which is then remobilised into the dissolved phase in the deep anoxic basin.

\section{Conclusions}

All the data discussed here point to the a new scenario for the main processes that control $\mathrm{Zn}$ and $\mathrm{Ni}$ isotopes in the modern global ocean. Uptake into cells for metabolic use dominates the outputs from the dissolved pool for $\mathrm{Zn}$, and probably also for Ni. But this process does not involve an isotope fractionation. The isotopes are, instead, controlled by conversion to sulphide in anoxic settings, a process that distinctly favours the light isotope, leaving the residual water heavy. There is still a mass balance problem, 
however. Though light $\mathrm{Zn}$ and $\mathrm{Ni}$ are removed in the water column of sulphidic basins like the Black Sea, the processing of water through such basins is nowhere near fast enough to explain the heavy $\mathrm{Zn}$ and $\mathrm{Ni}$ isotope compositions of the global open ocean. Recently, we have also discovered that organic-rich sediments beneath open-ocean upwelling zones contain isotopically-light authigenic $\mathrm{Zn}$ (Little et al. 2016). The transfer of metals to the sediment is driven here by high primary productivity in the photic zone above them, and these settings are quantitatively much more important outputs than those such as the Black Sea, settings that are not particularly productive but become sulphidic at depth simply because of the restriction of their circulation. Combining these observations, we suggest that it is the partial sulphidisation of the metal inventory contained in organic matter in the anoxic sediments that characterise upwelling zones, the sequestration of the light isotopes to sulphide within the sediment, and the release back to the water column of the isotopically heavy residual dissolved signal, that controls seawater isotope compositions. Though this hypothesis greatly de-emphasises what we can learn about the past biosphere from these isotope systems, it opens up new and exciting potential for their use in understanding past ocean redox.

\section{Compliance with ethical standards}

Conflicts of interest On behalf of all authors, the corresponding author states that there is no conflict of interest.

Open Access This article is distributed under the terms of the Creative Commons Attribution 4.0 International License (http://crea tivecommons.org/licenses/by/4.0/), which permits use, duplication, adaptation, distribution and reproduction in any medium or format, as long as you give appropriate credit to the original author(s) and the source, provide a link to the Creative Commons license and indicate if changes were made.

\section{References}

Bruland KW, Lohan MC, Middag RH (2014) Controls of trace metals in seawater. In: Mottl MJ, Elderfield $\mathrm{H}$ (eds) Treatise on geochemistry, 2nd edn, vol 8, pp 19-51

Conway TM, John SG (2014) The biogeochemical cycling of zinc and zinc isotopes in the North Atlantic Ocean. Glob Biogeochem Cycle 28:1111-1128

Fujii T, Moynier F, Blichert-Toft J, Albarède F (2014) Density functional theory estimation of isotope fractionation of $\mathrm{Fe}, \mathrm{Ni}$, $\mathrm{Cu}$ and $\mathrm{Zn}$ among species relevant to geochemical and biological environments. Geochim Cosmochim Acta 140:553-576

John SG, Geis RW, Saito MA, Boyle EA (2007) Zn isotope fractionation during high-affinity and low-affinity zinc transport by the marine diatom Thalassiosira oceanica. Limnol Oceanogr 52:27102714

Köbberich M, Vance D (2017) Kinetic control on Zn isotope signatures recorded in marine diatoms. Geochim Cosmohcim Acta (in press)

Little SH, Vance D, McManus J, Severmann S (2016) Key role of continental margin sediments in the oceanic mass balance of $\mathrm{Zn}$ and $\mathrm{Zn}$ isotopes. Geology 44:207-210

Morel FMM, Milligan AJ, Saito MA (2014) Marine bioinorganic chemistry: the role of trace metals in the oceanic cycles of the major nutrients. In: Mottl MJ, Elderfield $\mathrm{H}$ (eds) Treatise on geochemistry, 2nd edn, vol 8, pp 123-149

Moynier F, Vance D, Fujii T, Savage P (2017) The isotope geochemistry of zinc and copper. Rev Miner Geochem 82:543-600

Vance D, Little SH, Archer C, Cameron V, Andersen MB, Rijkenberg MJA, Lyons TW (2016) The oceanic budget of nickel and zinc isotopes: the importance of sulphidic environments as illustrated by the Black Sea. Phil Trans Roy Soc A Phys Sci 374, paper ID 20150294

Vance D, Little SH, de Souza GF, Khatiwala SP, Lohan MC, Middag R (2017) Silicon and zinc biogeochemical cycles coupled through the Southern Ocean. Nat Geosci 10:202-206 